\title{
Litigating Women
}

This edited collection, written by both established and new researchers, reveals the experiences of litigating women across premodern Europe and captures the current state of research in this evergrowing field.

Individually, the chapters offer an insight into the motivations and strategies of women who engaged in legal action in a wide range of courts, from local rural and urban courts, to ecclesiastical courts and the highest jurisdictions of crown and parliament. Collectively, the focus on individual women litigants rather than how women were defined by legal systems - highlights continuities in their experiences of justice, while also demonstrating the unique and intersecting factors that influenced each woman's negotiation of the courts. Spanning a broad chronology and a wide range of contexts, these studies also offer a valuable insight into the practices and priorities of the many courts under discussion that goes beyond our focus on women litigants.

Drawing on archival research from England, Scotland, Ireland, France, the Low Countries, Central and Eastern Europe, and Scandinavia, Litigating Women is the perfect resource for students and scholars interested in legal studies and gender in medieval and early modern Europe.

Teresa Phipps is a social historian of late medieval England and Wales, interested in women, law, and urban society. Publications include a monograph on women and justice in late medieval English towns (2020), a volume on medieval town courts (2019), and articles on coverture, trespass, and credit.

Deborah Youngs is a Professor of History at Swansea University, UK, with research interests in the social, legal and cultural histories of late medieval England and Wales. She is currently researching and publishing on women's litigation in the English court of Star Chamber.

\section{Litigating Women}

\section{Gender and Justice in Europe, c.1300-c.1800}

\section{Edited by Teresa Phipps and Deborah Youngs}

First published 2022

by Routledge

2 Park Square, M ilton Park, Abingdon, Oxon OX14 4RN

and by Routledge

605 Third Avenue, New York, NY 10158

Routledge is an imprint of the Taylor \& Francis Group, an informa business 
(C) 2022 selection and editorial matter, Teresa Phipps and Deborah Youngs; individual chapters, the contributors

The right of Teresa Phipps and Deborah Youngs to be identified as the authors of the editorial material, and of the authors for their individual chapters, has been asserted in accordance with sections 77 and 78 of the Copyright, Designs and Patents Act 1988.

All rights reserved. No part of this book may be reprinted or reproduced or utilised in any form or by any electronic, mechanical, or other means, now known or hereafter invented, including photocopying and recording, or in any information storage or retrieval system, without permission in writing from the publishers.

Trademark notice: Product or corporate names may be trademarks or registered trademarks, and are used only for identification and explanation without intent to infringe.

British Library Cataloguing-in-Publication Data

A catalogue record for this book is available from the British Library

Library of Congress Cataloging-in-Publication Data

A catalog record has been requested for this book

ISBN: 978-0-367-23030-2 (hbk)

ISBN: 978-0-367-23028-9 (pbk)

ISBN: 978-0-429-27803-7 (ebk)

DOI: $10.4324 / 9780429278037$

Typeset in [font]

by [Typesetter]

\section{Contents}

Acknowledgements

List of figures

List of tables 
List of contributors

Introduction

1. Mothers and daughters and sons, in the law: family conflict, legal stories, and women's litigation in late medieval M arseille

Susan McDonough

2. Consent and coercion: women's use of marital consent laws as legal defence in late medieval Paris

Kristi DiClemente

3. Shades of consent: abduction for marriage and women's agency in the late medieval Low Countries

Chanelle Delameillieure

4. Female litigants in secular and ecclesiastical courts in the lands of the Bohemian Crown, c.1300-c.1500

Michaela Antonín Malaníková

5. Widowhood and attainder in medieval Ireland: the case of Margaret Nugent

Sparky Booker

6. Choosing Chancery? Women's petitions to the late medieval court of Chancery Cordelia Beattie

7. Gendered roles and female litigants in north-eastern England, 1300-1530

Peter L. Larson

8. Property over Patriarchy? Remarried widows as litigants in the records of Glasgow's commissary court, 1615-1694

Rebecca Mason

9. Women negotiating wealth: gender, law and arbitration in early modern southern Tyrol Margareth Lanzinger and Janine Maegraith 
10. A litigating widow and wife in early modern Sweden: Lady Elin Johansdotter [Månesköld] and her family circle

Mia Korpiola

11. Women litigants in early eighteenth-century Ireland

Mary O'Dowd

12. Hidden in plain sight: female litigators, reproductive lives, archival practices and early modern historiography

Julie Hardwick

\section{Bibliography}

Index

\section{List of figures}

10.1 Simplified Family Tree of Lady Elin Johansdotter [Månesköld]

\section{List of tables}

4.1 Typology of lawsuits of marital disputes in the Judicial Act Books of the vicar general's court, years $1421-1424$

4.2 Typology of lawsuits of marital disputes in the Judicial Act Books of the vicar general's court, years 1427-1437 (based on Zittauer Urkundenbuch)

7.1 Manors and sources examined

8.1 Types of court cases dealt with by Glasgow's Commissary Court, 1615-1645 and 1658-1694

8.2 Sex of plaintiffs in litigation in Glasgow's Commissary Court, 1615-1645 and 1658-1694

8.3 Sex of defendants in litigation in Glasgow's Commissary Court, 1615-1645 and 1658-1694

8.4 Marital and relational status of female litigants in Glasgow's Commissary Court, 1615-1645 and 1658-1694

\section{List of contributors}


Cordelia Beattie is senior lecturer in medieval history at the University of Edinburgh, Scotland. She has published widely on medieval women and gender, and is the author of Medieval Single Women (2007) and editor of the four-volume Women in the M edieval World (2017).

Sparky Booker is assistant professor of history at Dublin City University, Ireland. She specialises in the social history of late medieval Ireland. Her publications in the area include articles on medieval sumptuary law (Speculum, 2021) and the Irish clergy (IHS, 2014) and an award-winning monograph, Cultural Exchange and Identity in Late Medieval Ireland (2018).

Chanelle Delameillieure is a postdoctoral researcher at KU Leuven, Belgium. Her research concerns medieval gender and family history, with a focus on marriage making and intergenerational family relations. She has published in Journal of Family History (2017) and co-edited a book (in Dutch) on medieval women (2019).

Kristi DiClemente is associate professor at M ississippi University for Women, USA, where she teaches ancient and medieval history. Her research examines marriage disputes in the Parisian archdeacon's court to uncover the married lives of medieval women, and their access to justice in fourteenth- and fifteenth-century Paris.

Julie Hardwick is J ohn E. Green Regents Professor of history and a Distinguished Teaching Professor at the University of Texas-Austin, USA. Her most recent book is Sex in an Old Regime City: young workers and intimacy in France, 1660-1789 (Oxford, University Press, 2020). For full details of her current and past work, see https://liberalarts.utexas.edu/history/faculty/jholwell.

Mia Korpiola is professor of legal history at the University of Turku, Finland (Faculty of Law). Her most important publications include Between Betrothal and Bedding (2009), Regional Variations in Matrimonial Law and Custom in Europe, 1150-1600 (ed., 2011) and Legal Literacy in Premodern European Societies (ed., 2019).

Margareth Lanzinger is professor of economic and social history at the University of Vienna, Austria. Her work focusses on kinship, family and marriage, property, inheritance practices and marital property regimes, including co-edited volumes on the domestic sphere (The Routledge History of the Domestic Sphere in Europe, 2020) and on negotiations of gender and property (Negotiations of Gender and Property through Legal Regimes, 2021).

Peter L. Larson is associate professor of history at the University of Central Florida, USA. His research focusses on late medieval and early modern northeastern England, and he is author of the forthcoming Reconsidering the Great Transition: Community and Economic Growth in County Durham, 1349-1660.

Janine Maegraith is research associate at the Department of Economic and Social History, University of Vienna, Austria, and works on the project "The Role of Wealth in Defining and Constituting Kinship Spaces". Her research focusses on early modern social and economic European history, specifically Tyrol 
and Upper Swabia. She has recently published on property transfer, exchange and inheritance in early modern Southern Tyrol in The History of the Family (2021).

Michaela Antonín Malaníková is assistant professor of medieval history at Palacký University Olomouc, Czech Republic. She has published articles and book chapters dedicated to, for example, medieval identity, or female engagement in urban economy. In her latest research project, she focusses on structures and functioning of late medieval urban families.

Rebecca Mason is an Economic and Social Research Council postdoctoral fellow at the University of Glasgow, Scotland. She holds a PhD in history from the University of Glasgow. Her current research focusses on women's access to justice in early modern Scotland. She has published on women's legal status and property rights in seventeenth-century Glasgow.

Susan M cDonough is associate professor of history at the University of M aryland, Baltimore County, USA. She studies women, gender and sexuality in the medieval M editerranean, especially sex workers and single women. She published Witnesses, Neighbors, and Community in Late M edieval Marseille (2013) and co-edited Boundaries in the Medieval and Wider World: Essays in Honor of Paul Freedman (2018).

Mary O'Dowd is professor emeritus of gender history in Queen's University Belfast, Northern Ireland. Her research focusses on the history of women and gender in Ireland. Her most recent publication is Marriage in Ireland, 1660-1925 (2020), c0-authored with M aria Luddy. 